\title{
Impact of the Covid-19 pandemic on the automotive industry in Slovakia and selected countries
}

\author{
Iveta Kufelová, ${ }^{*}$, Monika Raková $^{2}$ \\ ${ }^{1}$ University of Economics in Bratislava, Faculty of Business Management, Department of Business \\ Economy, Dolnozemská cesta1, 85235 Bratislava, Slovak republic \\ ${ }^{2}$ University of Economics in Bratislava, Faculty of Business Management, Department of Business \\ Economy, Dolnozemská cesta1, 85235 Bratislava, Slovak republic
}

\begin{abstract}
The new coronavirus has far-reaching economic impacts all over the world and, due to the openness of the Slovak economy, it also has an impact on Slovak companies as well as car plants. Except that paralyzed European demand for vehicles, as well as the entire supply chain. The result was the fact that there was no one to make or something to make. And so the manufacturers, together with the suppliers, closed their productions for operational and hygienic reasons. However, this will have a very big impact on the economy as a whole, as the car industry is a fundamental pillar. The paper is pointed to highlight the current effects of the pandemic and measures in the automotive industry in Slovak republic and selected countries.
\end{abstract}

\section{Introduction}

The virus, which is faced by almost all countries of the world, has affected all countries and economies of Western Europe. Many of them have adopted restrictive measures that have slowed, paralyzed and even stopped the economy. As in European countries, the economies of the United Kingdom and the United States can be expected to weaken, especially due to the late response to the current situation. For this reason, a recession can be expected in 2020 not only in Europe but also in the USA. and in the euro area by $6 \%$ or more. The Italian economy is most likely to be affected. The Slovak economy could decline by approximately 11 to $12 \%$ ( $7.2 \%$ of GDP). The reasons for this decrease stem from the following situations. Due to the spread of the COVID-19 pandemic, all schools and school facilities in Slovakia were gradually closed. Subsequently, all retail outlets were closed, except for food and drugstores, which caused the household services sector to be completely shut down. (restaurant, cultural, recreational sports, etc.) This sector was the first to fully feel the effects of restrictive measures in its business. Gradually, self-employed people, who did not have the opportunity to buy various consumables, to close their business activities were closing down.

\footnotetext{
* Corresponding author: iveta.kufelova@euba.sk
} 
After the closure of restaurants, shops and, consequently, manufacturing companies, there was a big drop in all statistics that capture economic life. Industrial production fell by 20 $30 \%$, retail sales by $40 \%$, restaurants and hotels by $80 \%$.

The following figure shows the added value according to the individual sectors of the national economy and points out which sectors will be most affected.
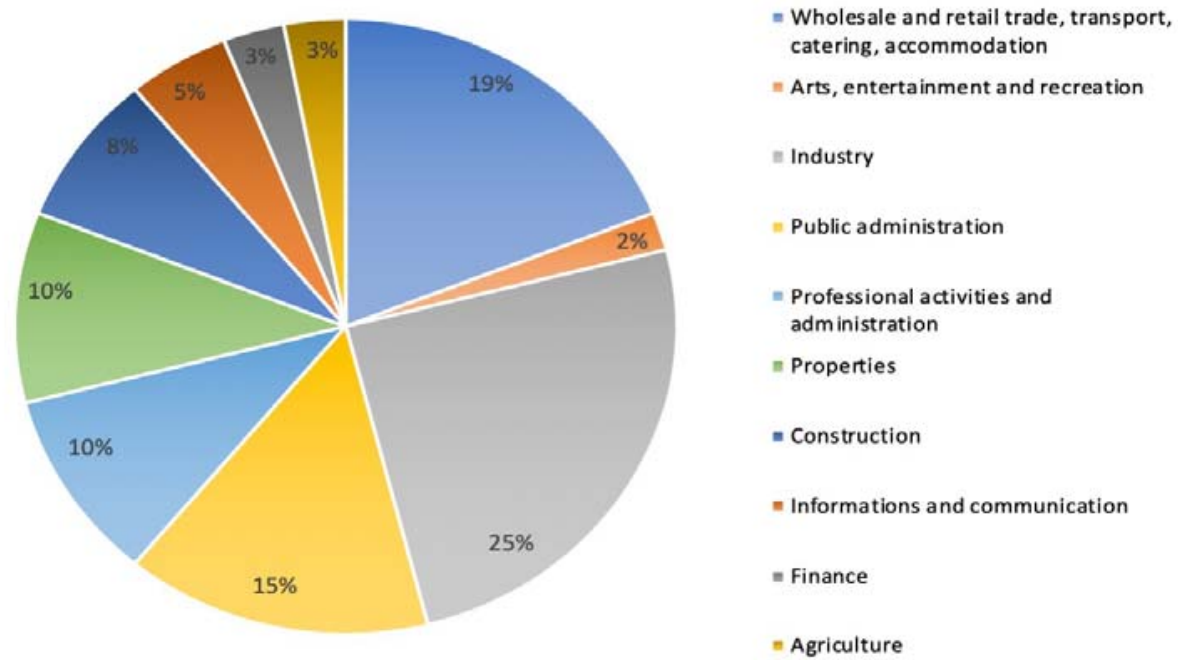

Figure 1. Added value of individual sectors of the national economy

From the above, it can be stated that the industry accounts for about 25 percent of total value added, followed by wholesale, retail, transport, catering, art, recreation contribute to the creation of added value by about $19 \%$. Of course, the suspension of business in this will also affect other sectors of the national economy.

\section{Characteristics of automotive industry}

According to history, manufacturing sectors is a key pillar of economic growth and development and until nowadays it becomes positively moderate for the economy.There are a few types of manufacturing industries which are textiles, food and beverages, aerospace and also automotive manufacturing. The automotive industry is a worldwide industry which has high competition all over the world. As the automotive sectors contribute high economic revenue for the country, the growth of the sectors should be intensified[2]. The role of the automotive industry in the economic structure and its impact on investment flows are assessed through social accounting matrices. Under the proposed methodology, the classification of sectors and the impact. [4] To boost up the sectors by incorporate strategies that help in increasing the production and quality, all issues that involve in the manufacturing should be solved. [3] Automobility is defined as self-organizing autopoetic, non-linear system that spreads worldwide, and includes cars, car-drivers, roads, petroleum supplies and many novel objects, technologies and signs. [1] 
Automotive industry is looking for both competitive materials and production processes, in order to act on a possible mass reduction and fuel economy which in turn involve a real improvement in the use of environmentally friendly products. [2] Automotive manufacturing is a complex and energy-intense process which consumes a significant quantity of raw materials and water. Toremain competitive, automotive original equipment manufacturers have to strive for better product quality by continuously improving their production process and driving towards low-carbonemissions and enhanced sustainability [5]

The automotive industry is a key industrial sector and economic pillar of several Central countries and Eastern Europe. This sector is one of the main sources of FDI in the region for the last 20 years. Car manufacturers use educated, productive and relatively cheap labor and quality connections with Western European markets as well as a favorable position for exports to the east. Slovakia is currently one of the important centers of the global automotive industry, producing the highest number of passenger cars per capita in the world. It owes its position mainly to the presence of modern ones three car races: Volkswagen (Bratislava); PSA Peugeot Citroën (Trnava) and KIA Motors (Žilina)

and global supply companies. The development of the automotive industry in Slovakia and its integration into the world's automotive centers began in. In the 1990s, when the German car company Volkswagen AG launched a car plant near Bratislava. This important step helped the development of the Slovak economy after the demise of the former markets CMEA and the cessation of arms production. The entry of the automobile company Volkswagen into Slovakia also began to build a supply chain, which attracted further investment in the country. Slovakia so has embarked on a new path of development of industrial production in the sectors: automotive and mechanical engineering.

\section{Methods}

The main aim of this paper is to point out the change in the automotive industry brought by the current pandemic situation in the world. The first part of the paper focuses on the characteristics of the automotive industry in general and pointing out its main importance in the Slovak Republic. In the results and discussion, it is tried to demonstrate how Covid-19 caused the closure of operations, and thus a decline in sales and profits in the automotive industry in 2020 not only in the Slovak republic but also in selected countries. In this paper there are used general methods to process the paper, especially the method of analysis, synthesis and deduction.

\section{Results and Discussions}

In this chapter there is tried to map the current situation in the automotive industry affected by the pandemic covid 19 not only in the Slovak Republic, but also in selected countries of the world. The figure 2 shows the sales of cars in the years 2018 and 2019 in the world before pandemic situation cause by Covid-19. Part of figure is also comparison between shown years. As it could be seen, production of car was break down at all over the world also before Covid-19 come into people lives and paralyzed economy. 


\begin{tabular}{|c|c|c|c|c|}
\hline & $2019^{8}$ & 2018 & $\%$ change $19 / 18$ & $\%$ share 2019 \\
\hline EUROPE & $18,548,160$ & $19,440,981$ & -4.6 & 25.0 \\
\hline European Union ${ }^{9}$ & $15,769,041$ & $16,644,609$ & $-5 \cdot 3$ & 21.3 \\
\hline Russia & $1,513,640$ & $1,527,928$ & -0.9 & 2.0 \\
\hline Turkey & 944,087 & 983,952 & -4.1 & 1.3 \\
\hline Ukraine & 6,367 & 5,659 & 12.5 & 0.0 \\
\hline Others: Europe ${ }^{10}$ & 315,025 & 278,833 & 13.0 & 0.4 \\
\hline NORTH AMERICA & $12,165,682$ & $12,968,219$ & -6.2 & 16.4 \\
\hline of which the United States & $7,452,191$ & $8,028,375$ & -7.2 & 10.1 \\
\hline SOUTH AMERICA & $2,676,738$ & $2,754,002$ & -2.8 & 3.6 \\
\hline of which Brazil & $2,449,242$ & $2,411,076$ & +1.6 & $3 \cdot 3$ \\
\hline ASIA & $39,179,376$ & $41,897,507$ & -6.5 & 52.9 \\
\hline China & $20,675,662$ & $22,726,556$ & -9.0 & $27 \cdot 9$ \\
\hline Japan & $8,187,935$ & $8,214,183$ & -0.3 & 11.0 \\
\hline India & $3,571,298$ & $3,987,912$ & -10.4 & 4.8 \\
\hline South Korea & $3,629,252$ & $3,692,685$ & -1.7 & 4.9 \\
\hline Indonesia & $1,028,782$ & $1,040,322$ & -1.1 & 1.4 \\
\hline Thailand & 955,105 & $1,057,504$ & $-9 \cdot 7$ & 1.3 \\
\hline Others: Asia ${ }^{11}$ & $1,131,342$ & $1,178,345$ & $-4 \cdot 0$ & 1.5 \\
\hline MIDDLE EAST/AFRICA & $1,537,412$ & $2,065,538$ & -25.6 & 2.1 \\
\hline
\end{tabular}

Figure 2 The car production in the world in 2018 and 2019 and its comparison

Due to the new covid 19 virus, sales of new cars in Russia in April 2020 fell by $72.4 \%$ compared to the previous year. The Association of European Enterprises states that production has slowed down and sales have almost completely stopped. In April, only 38,922 new cars and light commercial vehicles were sold in Russia, which recorded the highest decline in sales. The most popular were Lada cars, which accounted for almost 9,395 vehicles in total sales. [6]

In April, car sales in Germany fell to the lowest monthly level since unification in 1990. Sales of new vehicles fell by 61 percent year-on-year to 120,840 units due to coronavirus restrictions. According to the automotive industry association VDA, car production in Germany almost stopped in April, falling by $97 \%$ year-on-year to 10,900 vehicles.

Sales of new passenger cars in Britain almost stopped in April due to coronavirus. It fell by about 97 percent to about 4,000 vehicles compared to last year when it was 161 thousand. It thus reached the lowest level since 1946. The car market in Britain has been hit hard by the temporary closure of car dealerships as part of measures against the spread of coronavirus. The British Association of Car Manufacturers and Dealers predicts that car sales in Britain will fall to 1.68 million in 2020 from 2.31 million last years.

Japanese carmakers fell global sales by a third to 1.82 million vehicles in March. The decline in sales due to the corona crisis will probably continue in the coming months. Toyota sales in March fell by $22.6 \%$ year on year to more than 779 thousand units, Nissan's sales fell by $43 \%$ to more than 315,000 cars. Worldwide sales of 7 Japanese automobiles for the fiscal year to March (Toyota, Nissan, Mazda and four other manufacturers) fell by $7.3 \%$ to 26.5 million, at least in four years. 
According to analysts, consumers will postpone the purchase of new cars. Global sales could fall by a third this year, falling by 11 percent at the height of the global financial crisis. [7]

In the Czech Republic, sales of new passenger cars fell by 53 percent to 1,0679 vehicles in April due to anti-coronavirus measures and lower overall demand. In four months, the market fell by $26.3 \%$ to 60,873 cars sold. The decline affected all segments and vehicle designs with the exception of electric and hybrid passenger cars. The registration of these vehicles increased year-on-year due to the pressure on car manufacturers through stricter emission limits. The biggest drop in sales was recorded by Volkswagen and Škoda vehicles. In the first four months, light commercial vehicles fell by 28 percent to 4,787 vehicles in the Czech Republic. Truck sales fell by 32 percent compared to the previous period to 2,278 vehicles. In April alone, it was a decrease of 52 percent. There was also a decrease in the sale of motorcycles by about $18 \%$. The carmaker Škoda Auto (in Mladá Boleslav) interrupted production on March 20, 2020 and employees remained in quarantine at home. The cessation of Škoda production will also affect employment in supplier companies. The carmaker itself employs approximately 34,000 people in the Czech Republic and another approximately 3,000 people through employment agencies. On March 25, Toyota Peugeot Citroën Automobile (TPCA) in Cologne stopped production due to the spread of the virus. The interruption could last until April 17. TPCA currently employs approximately 2,500 employees and the company is one of the largest exporters in the Czech Republic and also the largest employer.

Another discontinued production of the Hyundai car plant in Nošovice in order to prevent the spread of the corona virus infection. Production was suspended for about three weeks. After strict hygienic measures, production at Automobilka Hyundai in Nošovice was 14.4. 2020 renewed. Initially, the company will work on two shifts and will cover up to 12,000 employees - 3,300 employees are employed by Hyundai in total and 8,700 are their direct suppliers. Employees stay at home for the time being from the night shifts and will receive $70 \%$ of the average earnings, or as substitutes in the day shift in the event of a failure. Toyota Peugeot Citroën Automobile (TPCA) has extended production shutdown due to a coronavirus pandemic. Production lines could start in Cologne in early May 2020. Škoda Auto Mladá Boleslav has also not resumed production yet. [8] [9] [11] [13]

\section{Automotive industry in Slovak republic}

The Slovak economy was subsequently further affected by the situation in the automotive industry, when Volkswagen Slovakia announced that it was closing its operations in Bratislava and in all European cities. Production was also suspended by other car manufacturers (PSA in Trnava, Jaguar in Nitra). The production of car from 2006 to 2017 is in figure 2 . 


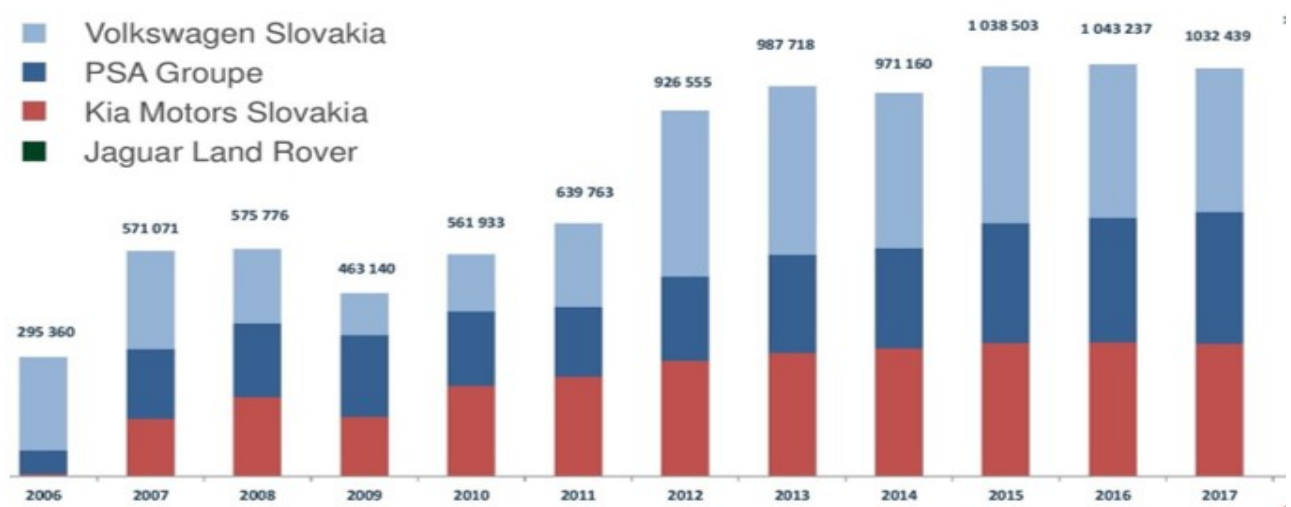

Figure 2 The car production from 2006 to 2017 in Slovak republic

Volkswagen Slovakia is a pillar of Slovak exports, one of the largest private employers and, together with its employees, also the largest contributor to public budgets. The company invested more than 4.5 billion euros during its operation in Slovakia. It currently employs 12,100 workers. It produces cars Volkswagen Touareg, Audi Q7, Audi Q8, Porsche Cayenne, Porsche Cayenne Coupé, Volkswagen up, SEAT Mii electric, ŠKODA CITIGOe $\mathrm{iV}$. In addition to vehicles, it produces gearboxes, components for gearboxes and chassis, as well as equipment used in the manufacture of vehicles.

VW plans to start production in the Spanish region of Navarre from April 20, 2020. This is where the VW Group has its production plant, which has been up and running since midMarch 2020. After the necessary hygiene measures have been taken, only one change will start for the first four days at first, and two after the implementation of the new processes and compliance with the measures. [10] [11]

Production at Jaguar Land Rover was suspended on March 20, when only selected Land Rover Defender production teams work at the plant, and those designed to provide the necessary operational activities.

Lastly, it closed the KIA operation in Žilina, which subsequently started production in a two-shift operation on April 7, 2020 due to orders from the countries of the Middle East, Africa and Asia. The resumption of production is carried out in accordance with all hygienic preventive measures, which are recommended by the crisis staff of the Slovak Republic and the regional public health office. At present, the KIA plant in Teplička nad Váhom employs more than 3,800 people in Slovakia, making it the main employer in the region. Kia Ceed models, the XCeed crossover and the Sportage sports-utility model are produced here. Since the start of production, the company has produced more than 3.4 million vehicles and 5 million engines.

Carmakers in Slovakia currently employ more than 177 thousand people. At the same time, they make up half of the total economy of our country. With their closure, the Slovak economy will be paralyzed for some time. The closure was, on the one hand, a response to declining demand in vehicle markets and supply chain constraints, and, on the other hand, a measure to close operations was necessary to prevent further spread of the virus.

The first quarter-on-quarter decline in GDP will be visible as early as the first quarter of 2020 and can be expected at 1\%, as January and February were still quite good. Subsequently, a decline of more than $10 \%$ can be expected in the second quarter.

From the third quarter, gradual economic growth can be expected not only in Slovakia but also in Western Europe. According to the above scenario, the recession should be Vshaped. [9] [10] [11] [12] 


\section{Conclusion}

The pandemic of the new coronavirus causing COVID-19 poses a global health threat with a direct impact on the economy. As the viruses know no borders, the governments of the affected countries had to take tough measures to slow the spread of COVID-19. One of the restrictions brought by pandemic was the closure of car production plants both in the world and also in the Slovak republic. This cessation of production will have the main impact on the country's GDP as the automotive industry because it is a pillar of the Slovak economy. From the point of view of the future development of Slovakia, it is therefore important to take such measures that will economically improve public administration, create favorable conditions for the activities of business entities in Slovakia and at the same time increase the level of preparedness for crisis situations in the future.

Such measures may be included tax reduction, saving in public administration, rationalize the social system, create flexible conditions on the labor market. State funds should focus primarily on funding teaching and research at universities of technology, science and medicine, to adopt the principles of financial policy of public administration (state administration and self-government), which will create financial reserves in addition to debt reduction.

This contribution is the result of the project VEGA no. 1/0368/18 "Cenové stratégie v prostredí pôsobenia efektívnych regulačných mechanizmov na nadnárodných trhoch siet'ových odvetví slovenskej ekonomiky" in extent $50 \%$ and the project IG no. I-20-10300 “in „Hodnotenie inovačného potenciálu v podmienkach nových manažérskych trendov na základe navrhnutých determinantov v automobilovom priemysle“extent $50 \%$.

\section{References}

[1] Wells, P., Wang, X., Wang, L., Liu, H., Orsato, R., 2020. More friends than foes? The impact of automobility-as-a-service on the incumbent automotive industry. Technological Forecasting and Social Change.. doi:10.1016/j.techfore.2020.119975

[2] Peter, I., Fracchia, E., Canale, I., Maiorano, R., 2019. Incremental sheet forming for prototyping automotive modules. Procedia Manufacturing.. doi:10.1016/j.promfg.2019.02.182

[3] Mohd Fazi, H.B., B Nik Mohamed, N.M.Z., Bin Basri, A.Q., 2019. Risks assessment at automotive manufacturing company and ergonomic working condition. IOP Conference Series Materials Science and Engineering.. doi:10.1088/1757-899x/469/1/012106

[4] Garcia-Remigio, C.M., Cardenete, M.A., Campoy-Muñoz, P., Venegas-Martínez, F., 2020. Valoración del impacto de la industria automotriz en la economía mexicana: una aproximación mediante matrices de contabilidad social. El Trimestre Económico.. doi:10.20430/ete.v87i346.852

[5] Giampieri, A., Ling-Chin, J., Ma, Z., Smallbone, A., Roskilly, A.P., 2020. A review of the current automotive manufacturing practice from an energy perspective. Applied Energy.. doi:10.1016/j.apenergy.2019.114074

[6] https://www.reuters.com/article/us-russia-autos-salesfigures/russia-car-sales-plunge-724-in-april-year-on-year-aeb-idUSKBN22O18C?il=0 
[7] https://www.reuters.com/article/us-japan-automakers-sales/march-global-sales-slumpspells-trouble-ahead-for-japans-carmakers-idUSKCN22A14C

[8] https://www.lidovky.cz/byznys/auto/nosovicka-automobilka-hyundai-obnovilavyrobu.A200414_070619_ln-auto_ele

[9] https://www.czso.cz/csu/czso/cri/miry-zamestnanosti-nezamestnanosti-a-ekonomickeaktivity-unor-2020

[10] https://ec.europa.eu/eurostat/web/lfs

[11] https://www.mfcr.cz/cs/verejny-sektor/makroekonomika/makroekonomickapredikce/2020/makroekonomicka-predikce-duben-2020-38089

[12] Sario. Automobilový priemysel.

https:/www.sario.sk/sites/default/files/content/files/automobilovy_priemysel_0.pdf 